\title{
Recreation potentials of urban forest parks
}

\author{
Alexander Tereshkin ${ }^{1}$, Olesya Azarova ${ }^{1, *}$, and Victoria Semenyutina ${ }^{2}$ \\ ${ }^{1}$ Saratov State Agrarian University named after N.I. Vavilov, 410012, 1, Theater sq., Saratov, Russian \\ Federation \\ ${ }^{2}$ Federal Scientific Centre of Agroecology, Complex Melioration and Protective Afforestation of the \\ Russian Academy of Sciences, 400062, 97 Universitskiy av., Volgograd, Russian Federation
}

\begin{abstract}
Recreational stress is a determining factor in the sustainability of forest ecosystems. Objects of research - green spaces of the forest park $51^{\circ} 33^{\prime} 14$ "N; $45^{\circ} 55^{\prime} 34^{\prime \prime}$ E (green zone of the city of Saratov, "Kumysnaya Polyana"). Purpose: identification and optimization of the recreational potential. The forest park is 4504 hectares. The largest indicators of bulk density $(1.35 \mathrm{~g} / \mathrm{cm} 3)$ were revealed in the service and recreation areas. For a separate section of the forest park, it is possible to increase the indicators of the recreational potential and capacity by 12.89 and $89.1 \%$. The recreation potential of the forest park is from 65 to 85 percent. Modernization of the zoning of the forest park, accomplishment of improvement works through sanitary and landscape felling, optimization of the road network will lead to an increase in the recreational capacity of leisure to 117.4 thousand people. Landscaping techniques have been developed.
\end{abstract}

\section{Introduction}

In recent years, great importance has been paid to the analysis of modern approaches to technologies for optimizing the recreation potential of forest parks $[1,2,3,8]$. A strategy for the formation of recreational and green spaces has been developed and an environmental justification has been made for the effectiveness of renewing the green fund $[5,6,10]$.

The recreational potential of the green zone is an integral indicator that takes into account a combination of factors that affect the attractiveness of recreation in a particular territory (OST 56-100-95). The main factor affecting the stability of forest ecosystems is the recreational load $[4,9]$. Exceeding the permissible level of visiting the territory of forest parks contributes to the degradation and depletion of phytocenoses, changes in the state and properties of the ground cover [7].

A scientific justification is required for an integrated approach to the study of forest ecosystems for a comparative assessment of compliance with the permissible limits of recreational loads. On its basis, the ecological and technological regulations for the functioning of forest parks are being developed. Realization of the recreational potential of the territories influences the aesthetics, ecology of space, logistics of tourist flows, and

\footnotetext{
*Corresponding author: soilzln@mail.ru
} 
promotes the creation of optimal conditions for relaxation and decorative durability of plantings.

\section{Methods}

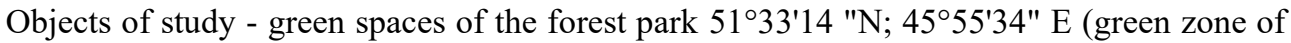
the city of Saratov). Forest park - 4504 hectares (Fig.1).

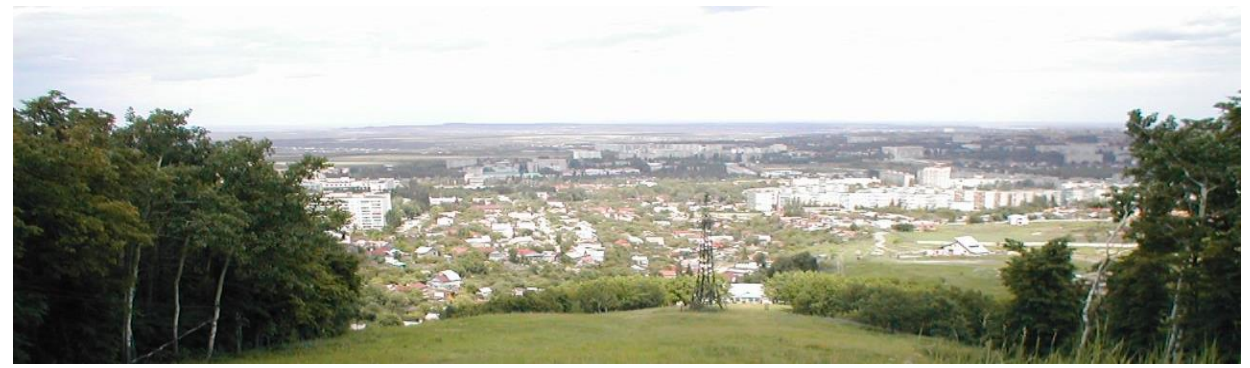

Fig.1. Forest Park.

The research program was carried out using current regulatory documents. Accounting for attendance and the level of recreational load at the research objects was carried out according to OST 56-100-95. For research, we adopted - registration and measurement method. The boundaries and areas of landscaping objects were determined using the following programs: Google Earth, CorelDrawX7 Graphic.

The survey sites at the research object were laid according to generally accepted methods. The characteristics of the recreation potential were calculated according to S.L. Rysin, 2003.

\section{Results}

Positive aspects for recreation are: the climate of the territory, features of the relief, diverse flora and fauna, developed transport routes, allowing you to rest almost all year round. Limiting factors include: lack of moisture, a large number of sunny days with a high level of insolation, stressful environmental conditions, paucity and low quality of water bodies.

Assessment of the state of forest areas within the transect showed that all their coefficients fall into the assessment group "High recreational potential" (attractiveness coefficient - $K_{a}=$ 0,708 ; comfort $-K_{c}=0,759$; sustainability $-K_{s}=0,647$ ). The value of the recreational potential of the plantations is $69.92 \%$.

At present, the territory is capable of accommodating about 55 thousand vacationers, or $6.57 \%$ of the city's population (Table 1). According to the current norms, this figure should be $15-20 \%$.

Table 1. Modern functional zoning and recreational capacity.

\begin{tabular}{|l|c|c|ccc|}
\hline \multirow{2}{*}{$\begin{array}{c}\text { Functional } \\
\text { zone }\end{array}$} & \multirow{2}{*}{$\begin{array}{c}\text { Square, } \\
\text { ha }\end{array}$} & \multicolumn{2}{c|}{ Permissible load } & \multicolumn{2}{c|}{$\begin{array}{c}\text { Recreational } \\
\text { capacity, people }\end{array}$} \\
\cline { 3 - 6 } & & Optimal & Maximum & Optimal & Maximum \\
\hline Recreational & 222 & 50 & 100 & 11100 & 22200 \\
Visitor service area & 57 & 100 & 200 & 5700 & 11400 \\
Agrolandscape & 488 & 1 & 2 & 488 & 976 \\
\hline
\end{tabular}


Tourist area

Conservation area

Economic zone

Total

376
87
3274
4504

$\begin{array}{ccc}10 & 1880 & 3760 \\ 5 & 174 & 435 \\ 5 & 6548 & 16370 \\ & 25890 & 55141\end{array}$

By changing the economic and agrolandscape zones, it is possible to optimize recreation (Table 2).

Table 2. Recommendations for optimization of areas for recreation.

\begin{tabular}{|l|c|c|c|c|c|}
\hline \multirow{2}{*}{$\begin{array}{c}\text { Functional } \\
\text { zone }\end{array}$} & \multirow{2}{*}{$\begin{array}{c}\text { Square, } \\
\text { ha }\end{array}$} & \multicolumn{2}{c|}{ Permissible load } & \multicolumn{2}{c|}{$\begin{array}{c}\text { Recreational } \\
\text { capacity, people }\end{array}$} \\
\cline { 3 - 6 } & & Optimal & Maximum & Optimal & Maximum \\
\hline Recreational & 450 & 50 & 100 & 22500 & 45000 \\
Visitor service area & 88 & 100 & 200 & 8800 & 17600 \\
Agrolandscape & 420 & 5 & 10 & 2100 & 4200 \\
Tourist area & 400 & 20 & 50 & 8000 & 20000 \\
Conservation area & 87 & 0,1 & 1 & 8,7 & 87 \\
Economic zone & 3059 & 5 & 10 & 15295 & 30590 \\
Total & 4504 & & & 56704 & 117477 \\
\hline
\end{tabular}

Table 3 shows the mathematical models for the regulation of recreational loads.

Table 3. Mathematical models of recreational load.

\begin{tabular}{llc|}
\hline Functional zone & \multicolumn{1}{c|}{ Mathematical model } & R2 \\
\hline Visitor service area & $y=0.8383 x^{3}-22.059 x^{2}+159.74 x-177.3$ & 0.8205 \\
Recreational & $y=0.4288 x^{3}-12.732 x^{2}+100.36 x-113.95$ & 0.8489 \\
Tourist area & $y=0.0598 x^{3}-3.042 x^{2}+31.674 x-37.213$ & 0.9023 \\
Agrolandscape & $y=0.032 x^{3}-1.1084 x^{2}+9.5745 x-10.258$ & 0.9506 \\
Conservation area & $y=0.0151 x^{3}-0.7408 x^{2}+7.3359 x-8.1009$ & 0.9336 \\
Economic zone & $y=0.1218 x^{3}-3.9638 x^{2}+33.796 x-37.57$ & 0.8967 \\
\hline
\end{tabular}

An optimized territory balance has been developed (Table 4).

Table 4. The balance of the designed territory.

\begin{tabular}{|c|c|c|c|c|}
\hline \multirow[t]{2}{*}{ Name } & \multicolumn{2}{|c|}{ Current state } & \multicolumn{2}{|c|}{$\begin{array}{c}\text { According to the } \\
\text { project }\end{array}$} \\
\hline & ha & $\%$ & ha & $\%$ \\
\hline $\begin{array}{l}\text { Green spaces } \\
\text { including } \\
\text { lawn } \\
\text { the trees } \\
\text { shrubs } \\
\text { flower beds }\end{array}$ & 293.05 & 90.7 & 134 & 60.4 \\
\hline Buildings and constructions & 0.15 & 0.04 & 3.2 & 1.4 \\
\hline Ponds & 2.8 & 1.2 & 2.8 & 1.2 \\
\hline Roads and paths & 25 & 0.6 & 38 & 17 \\
\hline Open spaces & 2 & 7.7 & 45 & 20 \\
\hline Total & 323 & 100 & 323 & 100 \\
\hline
\end{tabular}


It is recommended to carry out sanitary and landscape felling of the forest stand, develop a network of footpaths, bicycle roads, and increase the level of landscaping (Table 5).

Table 5. Optimization of the functional zoning of the territory.

\begin{tabular}{lccc|}
\hline Functional zone & Existing area & Projected area & Change \\
\hline Recreational & 222 & 450 & 228 \\
Visitor service area & 57 & 88 & 31 \\
Agrolandscape & 488 & 420 & -68 \\
& & & 24 \\
Tourist area & 376 & 400 & 0 \\
Conservation area & 87 & 87 & -215 \\
Economic zone & 3274 & 3059 & 0 \\
Total & 4504 & 4504 & \\
\hline
\end{tabular}

\section{Discussion}

Research on the current state and optimization of the recreational potential was carried out in the forest park $51^{\circ} 33^{\prime} 14$ "N; $45^{\circ} 55^{\prime} 34^{\prime \prime}$ E (green zone of Saratov, "Kumysnaya Polyana"). The highest indicators of bulk density $\left(1.35 \mathrm{~g} / \mathrm{cm}^{3)}\right.$ were determined in the service and recreation areas.

Assessment of the state of forest areas within the transect showed that all their coefficients fall into the "High recreational potential" assessment group (attractiveness coefficient $-K_{a}=0.708$; comfort $-K_{c}=0.759$; sustainability $-K_{s}=0.647$ ). The value of the recreational potential of the plantings is $69.92 \%$.

\section{Conclusion}

Currently, the territory is able to accommodate about 55 thousand tourists, or $6.57 \%$ of the city's population. According to the current norms, this figure should be $15-20 \%$. By changing the economic and agrolandscape zones, you can optimize your rest. Landscaping techniques have been developed. They are able to increase the indicators of recreational potential and capacity by 12.89 and $89.10 \%$, respectively. Modernization of the zoning of the forest park, accomplishment of improvement works through sanitary and landscape felling, optimization of the road network will lead to an increase in the recreational capacity of leisure to 117.4 thousand people.

\section{References}

1. Chiesura, Urban Plan, 68 (2004)

2. T. Dudek, Recreational potential of Rzeszów suburban forests versus the demand for spending leisure time in forests among the residents of the Podkarpackie Province (Sylwan), 160, 2 (2016)

3. E. Gómez-Baggethun, D. N. Barton, Ecol. Econ., 86 (2013)

4. R. Haines-Young, M. Potschin-Young, Common International Classification of Ecosystem Services (CICES) V5.1 and Guidance on the Application of the Revised Structure (2015)

5. E. Heyman, B. Gunnarsson, M. Stenseke, et al., Urban Forestry \& Urban Greening, 10, $4(2011)$

6. M. Marzano, N. Dandy, Forestry Commission (Edinburgh), 42 (2012) 
7. M. M. Podkolzin, I. P. Svintsov, Reputatiology, 39, 1 (2016)

8. S. L. Rysin, Forestry information, 1 (2003)

9. A. V. Semenyutina, I. Y. Podkovyrov, A. Sh. Huzhahmetova, V. A. Semenyutina, G. V. Podkovyrova, International Journal of Pure and Applied Mathematics, 2 (2016)

10. Skłodowski, P. Gołos, Preferred type of forest stand and factors deciding about the tourist attractiveness of the forest (Sylwan), 159, 9 (2015) 